УДК 616.314-089.28-076

DOI: $10.26435 /$ UC.V0I1(38).650

\author{
В.В. Глинкин, В.А. Клёмин
}

ГОО ВПО «Донецкий национальный медицинский университет имени М. Горького», Донецк

\title{
СПОСОБ ЭНДОДОНТИЧЕСКОЙ ПОДГОТОВКИ ОБРАЗЦОВ IN VITRО И ПРИГОТОВЛЕНИЯ ШЛИФОВ ЗУБОВ ДЛЯ ИССЛЕДОВАНИЯ НА СКАНИРУЮЩЕМ ЭЛЕКТРОННОМ МИКРОСКОПЕ
}

Изучение твердых тканей зубов с их прижизненной сохранностью, оценка качества используемых для лечения зубов пломбировочных материалов в настоящее время являются сложной морфологической проблемой [1]. В последние годы с помощью электронного микроскопа активно проводятся различные исследования зубов [2, 3], в том числе с использованием пломбировочных материалов $[4,5]$, изучается элементный химический состав твердых тканей зубов [6]. Были разработаны способы визуализации корневого канала удаленного зуба за счет увеличения пористости зуба и его деминерализации [7], нивелирования оптической плотности дентина удаленного зуба с целью оценки качества препарирования и пломбирования корневого канала [8].

Существует несколько способов изготовления препаратов прижизненно сохраненных зубов. Они используются для изучения твердых тканей зубов в отраженном свете с помощью светового микроскопа, для исследований, проводимых с помощью сканирующего электронного микроскопа (СЭМ), и трансмиссионно (с помощью просвечивающего электронного микроскопа - ПЭМ). Последние наиболее важны, т.к. позволяют исследовать структуры, находящиеся вне видимости светового микроскопа. Электронный микроскоп - это прецизионный прибор, который требует сложной подготовки исследуемых объектов. Одной из сложностей является сохранение структуры биологического объекта, содержащего в своем составе молекулы воды, которая будет нарушать вакуум. Поэтому существуют определенные этапы подготовки биологических объектов для изучения с помощью СЭМ [9].

Известен способ изготовления препаратов прижизненно сохраненных зубов для многоцелевых исследований, взятый в качестве прототипа, который заключается в следующем. Удаленные зубы промывают в физиологическом растворе, а затем фиксируют в 4-процентном растворе глютарового альдегида на фосфатном буфере в холодильнике в течение 4 суток. После этого зуб промывают, дегидратируют в режиме плавного перехода от спиртов к ацетону, а затем от ацетона к эпоксидной смоле. Все это проводят с двойным удлинением времени на каждом этапе. Затем зуб заливают в эпоксидную смолу с большим, чем в инструкции, содержанием отвердителя. После длительной полимеризации полученный блок разрезают сепарационным диском с последующей щадящей шлифовкой до получения ровного шлифа [10]. Недостатком данного способа является то, что он требует длительных временных затрат, обработка образца в агрессивных средах приводит к нарушению микроэлементного состава зуба, что влечет за собой косвенное изучение неорганической структуры зуба.

Известен способ подготовки зубов для исследования на электронном микроскопе качества пломбирования корневых каналов. После удаления зубы промывали проточной водой, погружали в дистиллированную воду или в 0,5процентный раствор хлорамин-Т-гидрата максимум на одну неделю. Затем зубы подвергали эндодонтической обработке по общепринятой методике, пломбировали каналы. Далее из зубов готовили шлифы, делая поперечные разрезы с последующим шлифованием мелкозернистыми эластичными дисками Sof-Lex фирмы $3 \mathrm{M}$, после чего шлифы протирали петролейным эфиром и протравливали 20 сек 36-процентной ортофосфорной кислотой [11].

Однако данный способ не обеспечивает создания влажной среды в области верхушки корня, что происходит во время пломбирования корня зуба в полости рта. Может быть травматичным для врача, осуществляющего эндодонтическое

(c) В.В. Глинкин, В.А. Клёмин, 2021

(c) Университетская Клиника, 2021 
лечение, т.к. зуб находится у него в руке. Этот способ малоинформативен при изучении тканей зуба на СЭМ ввиду отсутствия качественной подготовки как самого образца, так и изготовленного из него шлифа, что в дальнейшем не гарантирует полноценного исследования.

Альтернативой резки образцов зубов для приготовления шлифов является раскалывание зубов микротомным ножом. Для этого после предварительной деорганификации в 8-10процентном растворе гипохлорита натрия образцы замораживают в жидком азоте [12]. Недостаток этого способа заключается в необходимости применять дорогостоящее специализированное оборудование и привлекать специально обученный персонал, прошедший обучение и инструктаж по технике безопасности при использовании криогенных жидкостей и криогенного оборудования.

С целью преодоления этих трудностей нами был разработан способ эндодонтической подготовки зубов in vitro с последующим приготовлением из них шлифов для исследования на сканирующем электронном микроскопе.

\section{ЦЕЛЬ ИССЛЕДОВАНИЯ}

Усовершенствование способа подготовки исследуемого образца, включающего в себя эндодонтическую подготовку in vitro, приготовление шлифов зубов для исследования на сканирующем электронном микроскопе, позволяющего уменьшить временные и материальные затраты, не отражающиеся на качестве полученных образцов.

\section{МАТЕРИАЛ И ОБСУЖДЕНИЕ}

После извлечения из полости рта зубы, предназначенные для изучения, промывают в дистиллированной воде с последующим погружением в нее для минимизации возможного воздействия различных факторов на изменение микроэлементного состава зуба.

Для эндодонтический подготовки к проведению исследований на СЭМ удаленные зубы погружают корнями до коронковой части зуба в С-силиконовый оттискной материал, например, Zeta plus, замешанный согласно инструкции по использованию. После застывания материала начинают работать с зубами по методике, применяемой в полости рта пациента для эндодонтического лечения и включающую в себя препарирование кариозной полости с целью создания доступа к корневым каналам, медикаментозную обработку кариозной полости антисептическими препаратами, эвакуацию путридного распада из корневых каналов согласно клиническим протоколам, механическое расширение корневых каналов на всю рабочую длину с использованием файлов 4-6 конусности. Просвет канала расширяется не менее чем на три размера по сравнению с первоначальной шириной, но не меньше чем до размера ISO 25.04, согласно существующему эндодонтическому протоколу. Антисептическую обработку корневых каналов осуществляют 5,2-процентным раствором $\mathrm{NaOCl}$ и препаратами, содержащими ЭДТА или лимонную кислоту, с последующим высушиванием каналов бумажными штифтами согласно клиническим протоколам. Пломбирование корневых каналов зуба проводят согласно инструкции к применению конкретного исследуемого материала. Кариозную полость герметично закрывают цементом, например Уницемом. После окончания работы зуб необходимо извлечь из силиконового оттиска и внутреннюю поверхность оттиска увлажнить физиологическим раствором с целью имитации условий, приближенных к физиологическим. Материал должен застывать в корневых каналах согласно времени, указанному в инструкции.

Затем образцы обезвоживают при комнатной температуре в спиртах возрастающей концентрации: 1-е -в 70-процентном этиловом спирте, 2-е - в 80-процентном, 3е - в 96-процентном. На каждой стадии обезвоживания образцы выдерживают 5 часов. Экспериментальные образцы сутки высушивают на воздухе в беспыльных условиях.

Затем изготавливают шлиф зуба по описанной далее методике:

1. Продольный (поперечный) распил корня удаленного зуба проводят алмазным сепарационным диском с таким расчетом, чтобы не было перегрева зуба, с целью недопущения растрескивания образца.

2. Полученный образец для исследований заливают эпоксидной смолой (соотношение смола : отвердитель - 9:1). После ее полимеризации (не менее 24 часов) поверхность шлифа полируют.

3. Полировка шлифа:

3.1. Шлифуют наждачной бумагой: ступенчато шероховатостью Р100, P240, P500, P1000, P2000.

3.2. Полируют ступенчато алмазными пастами зернистостью 10/7, 5/3, 1/0.

3.3. Полируют универсальной алмазной суспензией (DiaDuo-2, зернистость 1,0 мкм).

3.4. Финишную полировку проводят коллоидной кремниевой суспензией (OP-S, зернистость 0,04 мкм).

4. На поверхность полученного шлифа наносят токопроводящий слой углерода методом напыления в установке, например ВУП-5А. 
5. Напыленный шлиф закрепляют на предметном столике, обеспечив надежный электрический контакт между поверхностью шлифа и столиком.

6. Предметный столик с закрепленным образцом помещают в колонну микроскопа для проведения исследований.

В предложенном способе эндодонтической подготовки образцов in vitro и приготовления шлифов зубов для исследования на сканирующем электронном микроскопе образец помещают в созданный силиконовый оттиск, в котором проводят все эндодонтические манипуляции в зубе, обеспечив создание влажной среды в области верхушки корня, дегидратацию проводят только в этиловом спирте, подготовку шлифов осуществляют с использованием ступенчатой шлифовки образца наждачной бумагой и полировки алмазными пастами, алмазной и кремниевой суспензиями.

Преимущества предложенного способа заключаются в сокращении времени и материальных затрат на осуществление способа, который не предусматривает использования токсических, дорогостоящих реактивов, безопасен для исполнителя и окружающей среды, не требует специального оборудования. Способ может быть осуществлен врачом-стоматологом любой квалификации. Данный способ приемлем для подготовки зубов и шлифов при исследовании морфологии и микроэлементного состава эндодонтических пломб и тканей зуба.

\section{В Ы В О д Ы}

Данный способ подготовки препаратов зубов для разнопланового микроскопического изучения с большой обзорной поверхностью обладает ценными качествами, позволяющими изучать разнородные комплексы, состоящие из тканей зуба и пломбировочных материалов, без предварительной декальцинации зубов, сохраняя их прижизненные морфологические особенности, а также сократить время и материальные затраты на осуществление способа. С помощью сканирующего электронного микроскопа возможно не только более глубокое изучение морфологии зубов и пломбировочных материалов подготовленных таким способом, но и определение их микроэлементного состава.

\section{В.В. Глинкин, В.А. Клёмин}

ГОО ВПО «Донецкий национальный медиџинский университет имени М. Горького», Донецк

\section{СПОСОБ ЭНДОДОНТИЧЕСКОЙ ПОДГОТОВКИ ОБРАЗЦОВ IN VITRО И ПРИГОТОВЛЕНИЯ ШЛИФОВ ЗУБОВ ДЛЯ ИССЛЕДОВАНИЯ НА СКАНИРУЮЩЕМ ЭЛЕКТРОННОМ МИКРОСКОПЕ}

В статье представлены данные о различных способах подготовки зубов для исследования на электронных микроскопах. Целью исследования является усовершенствование способа подготовки исследуемого образца, включающего в себя эндодонтическую подготовку in vitro, приготовление шлифов зубов для исследования на сканирующем электронном микроскопе, позволяющего уменьшить временные и материальные затраты, не отражающиеся на качестве полученных образцов. Удаленные зубы перед эндодонти- ческой обработкой помещают в С-силиконовую форму, а после проведенной эндодонтической манипуляции зубы дегидратируют и приготавливают шлифы из них посредством ступенчатой шлифовки и полировки исследуемой поверхности. Это позволяет изучать ткани зуба, сохраняя их прижизненные морфологические особенности, пломбировочные материалы, определять их микроэлементный состав.

Ключевые слова: шлифы зубов, электронный микроскоп, способ.

\section{V.V. Glinkin, V.A. Klyomin}

SEI HPE «M. Gorky Donetsk National Medical University», Donetsk

\section{METHOD FOR ENDODONTIC PREPARATION OF SAMPLES IN VITRO AND PREPARATION OF DENTAL GRINDERS FOR RESEARCH ON A SCANNING ELECTRONIC MICROSCOPE.}

The article presents data on various methods of preparing teeth for examination with electron microscopes. The aim of the study is to improve the method for preparing a test sample, including endodontic preparation in vitro, preparation of thin sections of teeth for examination on a scanning electron microscope, which makes it pos- sible to reduce time and material costs that do not affect the quality of the samples obtained. The extracted teeth are placed in a C-silicone mold before endodontic treatment, and after the endodontic manipulation, the teeth are dehydrated and thin sections are prepared from them by means of stepwise grinding and polishing of the stud- 
ied surface. This makes it possible to study the tooth tissues, preserving their morphological features, filling materials, and determine their microelement composition.
Key words: thin sections of teeth, electron microscope, method.

\section{ЛИТЕРАТУРА}

1. Костиленко Ю.П., Бойко И.В. Метод изготовления препаратов прижизненно сохраненных зубов для многоцелевых исследований. Клінічна анатомія та оперативна хірургія. 2004; 3(2): 63-65.

2. Глинкин В.В., Клемин В.А., Глинкина В.В. Особенности обработки корневых каналов при лечении хронических форм апикального периодонтита в стадии обострения. Инновационное развитие: потенциал науки и современного образования: монография/ под общ. ред. Г. Ю. Гуляева. Пенза: МЦНС «Наука и Просвещение»; 2019: 125-138.

3. Глинкин В.В., Клемин В.А., Зайка Т.О., Юлдашева Н.Р., Иброхимов А.А. Изменения микроэлементного состава гиппокампа и твердых тканей зуба крысы в результате стрессового воздействия на организм. Stomatologiya. $2019 ; 4: 14-18$.

4. Rosa R.A., Santini M.F., Heiden K. SEME valuation of the Interface Between Filingand Root-End Filling Materials. Scanningvol. 1999; 2013: 1-6.

5. Helder Fernandes Oliveiraa, Ana Helena Gonçalves Alencara, José Antônio Poli Figueiredob, Orlando Aguirre Guedesc, Danielde Almeida Decurcioa, Carlos Estrelaa. Evaluation of Marginal Adaptation of Root-End Filling Materials Using Scanning Electron Microscopy. Iranian Endodontic Journal. 2013; 8(4):182-186.

6. Орлов А.К. Особенности течения и лечение гиперестезии твердых тканей зубов у людей пожилого и старческого возраста: автореф. дис.... канд. мед. наук. СанктПетербург; 2015. 23.

7. Пяткова И.В., Субботина Т.Ф., Порхун Т.В. Патент РФ № $2373582 \mathrm{C} 1 ; 2009$.

8. Мосиенко Н.М. Патент РФ № 2478234 С2; 2013.

9. Немова С.В. Подготовка образцов для просвечивающей и сканирующей электронной микроскопии: новые установки от Leicamicrosystems для нанесения покрытий. Наука та інновації. 2014; 10 (2): 55-60.

10. Кашников П.А. Применение гидроксиапатита и лазерного излучения для профилактики осложнений при ортопедическом лечении дефектов зубов и зубных рядов несъемными протезами; автореф. дис. ... канд. мед. наук. Москва; 2014. 23.

11. Силантьева Т.А., Горбач Е.Н. Подготовка образцов биологических тканей для исследования в сканирующемэлектронном микроскопе с использованием камфена. Фундаментальные исследования. 2015; 2-22: 4919-4923.

12. Борисенко А.В., Дудик Е.П. Электронно-микроскопическое исследование присоединения разных групп силлеров к гуттаперчивым штифтам и к стенке корневого канала. Современная стоматология. 2007; 3: 2932 .

\section{REFERENCES}

1. Kostilenko Yu.P., Bojko I.V. Metod izgotovleniya preparatov prizhiznenno sohranennyh zubov dlya mnogocelevyh issledovanij [Method of preparing intravenously preserved teeth for multipurpose research]. Klinichna anatomiya ta operativna hirurgiya. 2004; 3(2): 63-65 (in Russian).

2. Glinkin V.V., Klemin V.A., Glinkina V.V. Osobennosti obrabotki kornevyh kanalov pri lechenii hronicheskih form apikal'nogo periodontita v stadii obostreniya [Features of root canal treatment in treatment of chronic forms of apical periodontitis in exacerbation stage]. Innovacionnoe razvitie: potencial nauki i sovremennogo obrazovaniya : monografiya [Innovative development: the potential of science and modern education: monograph] / pod obshch. red. G. YU. Gulyaeva. Penza: MCNS «Nauka i Prosveshchenie»; 2019: 125-138 (in Russian).

3. Glinkin V.V., Klemin V.A., Zajka T.O., YUldasheva N.R. Ibrohimov A.A. Izmeneniya mikroelementnogo sostava gippokampa i tverdyh tkanej zuba krysy v rezul'tate stressovogo vozdejstviya na organizm [Changes in the microelement composition of the hippocampus and solid tissues of the rat tooth as a result of stress on the body]. Stomatologiya. 2019; 4: 14-18 (in Russian).

4. Rosa R.A., Santini M.F., Heiden K. SEME valuation of the Interface Between Filingand Root-End Filling Materials. Scanningvol. 1999; 2013: 1-6.

5. Helder Fernandes Oliveiraa, Ana Helena Gonçalves Alencara, José Antônio Poli Figueiredob, Orlando Aguirre Guedesc, Danielde Almeida Decurcioa, Carlos Estrelaa. Evaluation of Marginal Adaptation of Root-End Filling Materials Using Scanning Electron Microscopy. Iranian Endodontic Journal. 2013; 8(4):182-186.

6. Orlov A.K. Osobennosti techeniya i lechenie giperestezii tverdyh tkanej zubov u lyudej pozhilogo i starcheskogo vozrasta: avtoref. dis.... kand. med. Nauk [Features of the course and treatment of hyperesthesia of hard tooth tissues in elderly and senile people: Cand.med.sci.diss.abs.] Sankt-Peterburg; 2015. 23 (in Russian).

7. Pyatkova I.V., Subbotina T.F., Porhun T.V. Patent RF № 2373582 S1; 2009 (in Russian)

8. Mosienko N.M. Patent RF № 2478234 S2; 2013 (in Russian).

9. Nemova S.V. Podgotovka obrazcov dlya prosvechivayushchej i skaniruyushchej elektronnoj mikroskopii: novye ustanovki ot Leicamicrosystems dlya naneseniya pokrytij [Preparation of samples for transmission and scanning electron microscopy: new installations from Leicamicrosystems for coating.]. Nauka ta innovaciï. 2014; 10 (2): 5560 (in Russian).

10. Kashnikov P.A. Primenenie gidroksiapatita i lazernogo izlucheniya dlya profilaktiki oslozhnenij pri ortopedicheskom lechenii defektov zubov i zubnyh ryadov nes»emnymi protezami: avtoref. dis. ... kand. med. Nauk [Use of hydroxyapatite and laser radiation for prevention of complications in orthopedic treatment of tooth defects and dental rows with permanent prostheses : Cand.med. sci.diss.abs.]. Moskva; 2014. 23 (in Russian).

11. Silant'eva T.A., Gorbach E.N. Podgotovka obrazcov biologicheskih tkanej dlya issledovaniya $\mathrm{v}$ skaniruyushchemelektronnom mikroskope $\mathrm{s}$ ispol'zovaniem kamfena [Preparation of biological tissue samples for examination in a scanning electron microscope using camphen]. Fundamental'nye issledovaniya. 2015; 2-22: 4919-4923 (in Russian).

12. Borisenko A.V., Dudik E.P. Elektronno-mikroskopicheskoe issledovanie prisoedineniya raznyh grupp sillerov $\mathrm{k}$ guttaperchivym shtiftam i k stenke kornevogo kanala [Electron microscopic examination of attachment of different groups of sillers to gutter pins and to the wall of the root canal]. Sovremennaya stomatologiya. 2007; 3: 29-32 (in Russian). 